\title{
For Shame: When High-Profile Shaming Is the Only Way to Get Things Discussed and Done
}

Kerri Lynn Stone

Florida International University College of Law, stonek@fiu.edu

Follow this and additional works at: https://ecollections.law.fiu.edu/faculty_publications

Part of the Civil Rights and Discrimination Commons, and the Courts Commons

\section{Recommended Citation}

Stone, Kerri Lynn, For Shame: When High-Profile Shaming is the Only Way to Get Things Discussed and Done, 48 Connecticut Law Review Online 1 (2016). 


\section{HEINONLINE}

Citation: 48 Conn. L. Rev. CONNtemplations 12016

Provided by:

FIU College of Law

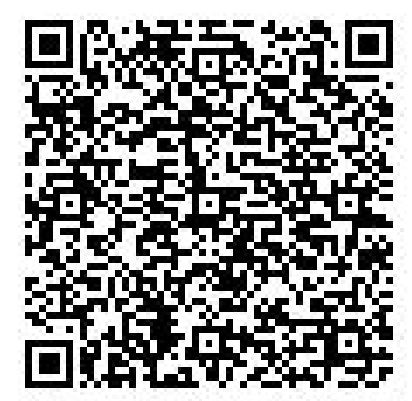

Content downloaded/printed from $\underline{\text { HeinOnline }}$

Tue Feb 21 15:30:05 2017

-- Your use of this HeinOnline PDF indicates your acceptance of HeinOnline's Terms and Conditions of the license agreement available at http://heinonline.org/HOL/License

-- The search text of this PDF is generated from uncorrected OCR text.

-- To obtain permission to use this article beyond the scope of your HeinOnline license, please use:

\section{Copyright Information}




\section{CONNECTICUT LAW REVIEW}

VOLUME 48

ONLINE

OCTOBER 2016

Essay

For Shame: When High-Profile Shaming Is the Only

Way to Get Things Discussed and Done

KERRI LYNN STONE 
4 


\title{
For Shame: When High-Profile Shaming Is the Only Way to Get Things Discussed and Done
}

\author{
KERRI LYNN STONE*
}

In recent years, the sports world has experienced a complex relationship with sex discrimination and bullying. On one hand, wellpublicized incidents of bullying, domestic violence, discrimination, and abuse have operated to alienate players, teams, and leagues from many of their fans. In some cases, these incidents have even led to rehabilitative public relations campaigns to combat the damage done to their public image. On the other hand, the fact that so many high profile incidents have occurred in such a public, much-talked-about sphere has actually served to aerate and vet issues in the court of popular opinion that would otherwise get no attention in the modern American workplace, or that would fail as claims brought in court under current constructions of the law.

In 2013-2014, the National Football League seemed beleaguered by crisis after crisis, ranging from multiple players' high profile arrests for domestic violence to the infamous Richie Incognito bullying scandal. ${ }^{1}$ The bullying scandal helped draw attention to an issue that had been neglected, if not scoffed at, in the American media and in state legislatures. ${ }^{2}$

\footnotetext{
* Professor of Law, Florida International University College of Law. An earlier version of this project benefited greatly from a workshop organized by Professor Howard Wasserman at the Southeastern Association of Law Schools Annual Meeting. Many thanks are due to my research assistant, Deedee Bitran. Thanks, as always to my husband, Joshua Stone, and my son, Dylan Stone, for all of their support.

'See, e.g., The NFL's Response to Domestic Violence and Sexual Assault, NFL.COM (Dec. 5, 2014), http://www.nfl.com/news/story/0ap3000000439286/article/the-nfls-response-to-domesticviolence-and-sexual-assault (stating that in the late summer of 2014, the NFL and Commissioner Roger Goodell came face-to-face with overwhelming public outcry, backlash and significant disappointment among the league's fan base after mishandling a very public act of domestic violence committed by one of its players, as well as additional high-profile abuse cases); Timeline of Dolphins' Alleged Bullying Saga Between Richie Incognito and Jonathan Martin, USA TODAY (Dec. 17, 2013), http://www.usatoday.com/story/sports/nfl/2013/11/07/richie-incognito-jonathan-martin-bullyingmiami-dolphins/3466755/ (providing a timeline of events in the Richie Incognito bullying scandal from October 30th, 2013 to December 16th, 2013); Michael Martinez \& Priscilla Riojas, NFL's Past Penalties for Domestic Violence 'A Different Story', CNN (Sept. 16, 2014), http://www.cnn.com/2014/09/09/us/nfl-players-domestic-violence-accusations/ (discussing the NFL's history of dealing with domestic violence by its players).

${ }^{2}$ See, e.g., The NFL's Response to Domestic Violence and Sexual Assault, NFL.COM (Dec. 5, 2014), http://www.nfl.com/news/story/0ap3000000439286/article/the-nfls-response-to-domesticviolence-and-sexual-assault ("This article is intended to provide both information and transparency as
} 
Workplace bullying is wholly lawful today. ${ }^{3}$ Moreover, in the media and in the court of public opinion alike, the issue had been largely ignored, or even dismissed as one worthy of being taken seriously. ${ }^{4}$ When public discourse turned to the trauma that professional football player and Stanford-educated Jonathan Martin had endured at the hands of Richie Incognito and his fellow teammates, the issue began-at last-to galvanize people, drawing their interest and spurring conversation about workplace bullying. ${ }^{5}$

In 2014-2015, baseball seemed to be at the center of several high profile scandals and lawsuits, with similar ironies. On one hand, the exposure of the sexually discriminatory and harassing "locker room culture" that pervaded even the corporate offices of teams was exposed, sparking discourse about the treatment and views of women within the sport. This alienated many women and many of those who support gender equality. On the other hand (and on a more positive note), certain events demonstrated the power of athletes and executives who are harassed and discriminated against to bring notoriety and attention to issues that get little legal attention, and to rights and prerogatives which are rarely vindicated under the law. Garnering this attention raises awareness, which, in turn, can actually help combat sex inequality, harassment, and discrimination in the workplace, the courts, and the legislatures.

Specifically, just to name a few examples, in September of 2014, former Mets Senior Vice President for Ticket Sales, Leigh Castergine, filed suit against the Mets, alleging that she was terminated after repeatedly being singled out and humiliated by the Mets' Chief Operating Officer for becoming pregnant out of wedlock. ${ }^{6}$ The suit settled in March of 2015, and

the league continues on what will be a very long journey towards making a real impact - inside and outside the NFL.").

${ }^{3}$ See Caroline Whittaker, Lyndon Davies \& Glyn Morris, Dealing with Workplace Bullying: The Occupational Health Nurse's Role, PERSONNEL TODAY (July 3, 2015), http://www.personneltoday.com/hr/dealing-workplace-bullying-occupational-health-nurses-role/ ("In legal terms, bullying is not covered by specific legislation, unlike harassment which is covered by legislation ... in particular the Equality Act.").

${ }^{4}$ See generally Ben Shpigel, 'A Classic Case of Bullying' on the Dolphins, Report Finds, N.Y. TIMES (Feb. 14, 2014), http://www.nytimes.com/2014/02/15/sports/football/investigation-finds-patternof-harassment-in-dolphins-locker-room.html (reporting that, despite widespread bullying among members of the Miami Dolphins football team, "[m]any of the Dolphins knew, but did not say or do anything ... [t]he players apparently considered this behavior part of the job.").

${ }^{5}$ See, e.g., Paul Palladino, Jonathan Martin on Dolphins Bullying: 'I don't think about it', SPORTS ILLUSTRATED (Mar. 31, 2015), http://www.si.com/nfl/2015/03/31/miami-dolphins-jonathanmartin-bullying-richie-icognito (stating that being bullied for the Dolphins was a "thing of the past"); Jenny Vrentas, The Wells Report, SPORTS Illustrated (July 8, 2014), http://mmqb.si.com/2014/07/08/nfl-history-in-95-ted-wells-report-miami-dolphins-locker-roomculture/ (discussing a report by the NFL that examined the internal cultures of each of its 32 teams).

${ }^{6}$ E.g., John Marzuli, Mets Co-Owner Jeff Wilpon Faces 14 Hours of Questioning in Gender $\begin{array}{llllll}\text { Discrimination Suit, N.Y. DAILY NEWS } & \text { (Nov. } & \text { 7, }\end{array}$ 
it is interesting to note that while she might well have prevailed in court due to the egregious facts, there are few judicial opinions on record that even address the issue of discrimination against single mothers. ${ }^{7}$ Moreover, although Castergine actually was fired and suffered an adverse action, had she not been, and had she needed to rely on a claim of sexual harassment only, the very high threshold for liability under that theory may or may not have been found to be present.

In April of 2014, Daniel Murphy of the New York Mets raised eyebrows and provoked criticism when he took off two games in a row to be with his wife immediately following the birth of his newborn son. ${ }^{8}$ As per the Wall Street Journal's Blog, "[t]hanks to a collective bargaining agreement, Murphy is assured the right to take up to three days off. However, among some baseball fans and many male members of the sports media, one would have thought Murphy robbed a bank."9

Harsh criticisms levied by broadcasters Boomer Esiason and Mike Francesa made the news. ${ }^{10}$ As per one Wall Street Journal blog:

"You're a Major League Baseball player," Francesa said on air. "You can hire a nurse to take care of the baby if your wife needs help."

"Quite frankly, I would have said C-section before the season starts. I need to be at opening day, I'm sorry," Esiason, a former NFL quarterback, said on his radio show. ${ }^{11}$

The backlash following these well-publicized barbs was swift and effusive. For example, as per the same Wall Street Journal blog:

Yankees broadcaster Michael Kay, on his ESPN New York radio show, said "I'd have to be an unbelievably narcissistic baboon to make my choice on somebody else and say that that person is wrong. That person has that right. It's a collectively bargained right . . . . Daniel Murphy was right

http://www.nydailynews.com/sports/baseball/mets/mets-co-owner-jeff-wilpon-faces-14-hourdeposition-article-1.2002957; Richard Sandomir, Mets Resolve Suit With Executive They Fired When She Was Pregnant and Unmarried, N.Y. TIMES (Mar. 13, 2015), http://www.nytimes.com/2015/03/14/sports/baseball/mets-settle-case-with-executive-who-citeddiscrimination-over-pregnancy.html.

${ }^{7}$ See Sandomir, supra note 6 (discussing the merits of Castergine's discrimination claim).

${ }^{8}$ Adam Rubin, Daniel Murphy: Right to Take Leave, ESPN.COM (Apr. 4, 2014), http://espn.go.com/mlb/story/_id/10721495/daniel-murphy-new-york-mets-deflects-criticism-takingpaternity-leave.

${ }^{9}$ Catherine Pearlman, Mets Player Daniel Murphy and Why Critics Cry Foul Over Paternity Leave, WALL ST. J. SPEAKEASY (Apr. 4, 2014), http://blogs.wsj.com/speakeasy/2014/04/04/metsslugger-daniel-murphy-and-why-critics-cry-foul-over-paternity-leave/.

${ }^{10} \mathrm{Id}$. 
for what Daniel Murphy wanted to do. Daniel Murphy wanted to be with his wife. Daniel Murphy wanted to be with his first child. And we're gonna [sic] sit here as all-knowing gods and say that he's wrong? How dare people?"12

He was not alone. From op-eds to online commentators to water cooler chitchat, the subject seemed to be everywhere for a while. Several interesting results came out of the ensuing backlash, discourse, and public debate sparked by the harsh criticism. For one thing, the issue of paternity leave and the way men who opt to take it are viewed and treated came to the forefront of current discourse. ${ }^{13}$ This marked a sharp departure from the silence that existed, and worse, the prevalence with which men were found to have been deterred from asking for leave after the birth of a child.

With respect to "paternity leave," it is interesting to note that the Family and Medical Leave Act ("FMLA") entitles covered male and female employees alike to take twelve weeks of unpaid leave after the birth or adoption of a child. ${ }^{14}$ Upon return to his or her job, the employee is entitled to his or her same salary, working conditions, and continuous benefits. ${ }^{15}$ Qualified employees must be employed by the federal government, a state or local government, ${ }^{16}$ or any company that has fifty or more employees employed within seventy-five miles of his or her workplace. ${ }^{17} \mathrm{He}$ or she must have also worked there for at least twelve months and for at least 1,250 hours during the previous year. ${ }^{18}$ Subject to a few exceptions, this is a guarantee that a father can take paternity leave and be protected from retaliatory action by an employer. Moreover, state laws often provide greater protections, with only a few states mandating a period of paid parental/family leave. ${ }^{19}$

There appear to be very few cases brought in which male plaintiffs have attempted to vindicate their right to leave after the birth of a child when they felt unable to take leave. Numerous articles have highlighted the way in which American men are, sometimes wordlessly, discouraged from taking paternity leave and discriminated against or

\footnotetext{
${ }^{12} \mathrm{Id}$.

${ }^{13}$ Jessica Grose, The Lesson From Baseball's Paternity Leave Controversy: Paternity Leave Is Not Controversial, SLATE: XX FACTOR (Apr. 7, 2014), http://www.slate.com/blogs/xx_factor/2014/04/07/mlb_paternity_leave_controversy_a_happy_ending to_the_boomer_esiason_flap.html.

${ }^{14} 29$ C.F.R. $\$ \$ 825.100,825.120,825.200(2013)$

${ }^{15} 29$ C.F.R. $\$ 825.100$ (c) (2013).

${ }^{16} 29$ C.F.R. $\$ 825.108$ (a) (2013)

1729 C.F.R. $\$ 825.110(\mathrm{a})(3)(2013)$.

${ }^{18} 29$ C.F.R. $\$ 825.110(\mathrm{a})(2)(2013)$.

${ }^{19}$ See National Conference of State Legislatures, State Family and Medical Leave Laws, NCSL (Dec. 31, 2014), http://www.ncsl.org/research/laborandemployment/statefamilyandmedical leavelaws.aspx (describing how paid family leave is only available in California, New Jersey, and Rhode Island).
} 
harassed for so much as suggesting that they might. ${ }^{20}$ According to the Society for Human Resource Management, the share of companies that offer paternity leave decreased from 2010 to 2014 by $5 \% .{ }^{21}$ Additionally, according to the White House Council of Economic Advisers, nearly one-third of males reported that they did not have a paternity leave option. ${ }^{22}$ Three quarters of men who do not receive paternity leave take off work for a week or less after the birth of a child. ${ }^{23}$ An article stated that $70 \%$ of men do not take paternity leave because of the negative social stigma attached to it. ${ }^{24}$ Further, men "often use sick or vacation days and cite work pressure and unwritten expectations as reasons for not taking longer leaves." 25 Indeed, a Westlaw search of: " "paternity leave' /p FMLA" yields only fifteen federal cases, and a search of “"paternity leave' /p 'Title VII" yields only nine federal cases.

As steeped in discriminatory beliefs and as riddled with gender insensitivity as the sports world and the things that go on in and around it can be, just as with the Incognito scandal, it took these things unfolding on the stage of the sports world for the average American worker - even in a white collar workplace - to have real attention turned to his plight ${ }^{26}$ Moreover, with the U.S. lagging far behind much of the rest of the industrialized world when it comes to legislation and rights afforded issues like workplace bullying and workplace support for new

\footnotetext{
${ }^{20}$ See, e.g., Kat Stoeffel, Men Not Interested in Paternity Leave, NYMAG.COM (June 13, 2013), http://nymag.com/thecut/2013/06/men-not-interested-in-paternity-leave.html ("In order to take the full six, men must 'affirm that they are the baby's primary caregiver' - a policy that seems designed to discourage workers from deviating from traditional gender roles. That, and all the mockery: 'A forthcoming paper from the University of Toronto ... found that men who are active caregivers get teased and insulted at work more than so-called traditional fathers and men without children."'); A Father's Place, THE ECONOMIST (May 16, 2015), http:/www.economist.com/news/international/21651203-men-have-long-been-discouraged-playingequal-role-home-last-starting ("Fathers who ask for more than a minimal time must prepare to be 'trailblazers' in their workplaces ....").

${ }^{21}$ Claire Cain Miller, Paternity Leave: The Rewards and the Remaining Stigma, N.Y. TIMES (Nov. 7, 2014), http://www.nytimes.com/2014/1 1/09/upshot/paternity-leave-the-rewards-and-theremaining-stigma.html?_r=0.

${ }^{22}$ Id.

23 Jason Hall, Why Men Don't Take Paternity Leave, Forbes (June 14, 2013), http://www.forbes.com/sites/learnvest/2013/06/14/why-men-dont-take-paternity-leave/

${ }^{24}$ See, e.g., Martin Williams, $40 \%$ of Fathers Do Not Take Paternity Leave, THE GuARDIAN (Jan. 6,2013 ), http://www.theguardian.com/careers/fathers-choose-not-to-take-paternity-leave ("70\% said they felt there was a social stigma attached to it, while a quarter thought it could damage their career in the future. Only a quarter of fathers who work part-time did not have any concerns about the option.").

${ }^{25}$ Miller, supra note 21.

${ }^{26}$ Doug Farrar, In the NFL, Bullying Awareness and Prevention Happens on a Case-by-Case Basis, SPORTS ILluSTRATED (Nov. 6, 2013), http://www.si.com/nfl/audibles/2013/11/06/richieincognito-jonathan-martin-bullying-nfl ("It will take the efforts of a lot of people to make that happen, and it starts with shifting the blame to the place it where it belongs -- away from the victim, and straight to the instigator. 52 years ago, Elston Howard did it with a fist. The NFL must do it with a culture change from top to bottom.").
} 
parents, having these issues accorded the prominence and publicity that they have long deserved is a boon for workplace equality. ${ }^{27}$ It seems that only in the aftermath of these sports-related incidents exploding in the media were these issues finally afforded this long-overdue attention.

The stigma surrounding being a victim of workplace bullying or a father wanting leave to be with his newborn has plagued even privileged, high earning workers for way too long. ${ }^{28}$ Ironically, the locker-room culture and sexist sensibilities in and around the sports world have pushed these issues into the cultural consciousness, helping to remove this stigma. Incognito was disciplined after his bullying scandal broke. ${ }^{29}$ Esiason eventually apologized for his comments about Murphy, but more significantly, public opinion looks to have turned on these issues. ${ }^{30}$ Public

27 See Katherine Reynolds Lewis, New Dads Confront Uphill Battle for Paternity Leave, FORTUNE (June 10, 2014), http://fortune.com/2014/06/10/fathers-paternity-leave/ ("Only 12\% of U.S. employers surveyed by the Society for Human Resource Management offer paid paternity leave, a stark contrast to the 70 other countries that have legislated paid paternity leave."); see generally, A Father's Place, THE ECONOMIST (May 16, 2015), http:/www.economist.com/news/international/21651203men-have-long-been-discouraged-playing-equal-role-home-last-starting ("some countries are giving fathers a firm nudge. In a few, including Chile, Italy and Portugal, paternity leave is compulsory. Others offer incentives that are hard to turn down."); ANTI-BULLYING ALLIANCE, http://www.antibullyingalliance.org.uk/ (last visited Feb. 28, 2016) ("Help us raise awareness of all forms of bullying and eradicate the fear of it for children and young people across England."); We're Tackling Bullying Across Europe Through the Enable Project, THE Diana AwARD's ANTI-BULlying CAMPAIGN (Jan. 30 , 2015), http://www.antibullyingpro.com/blog/2015/1/30/were-tackling-bullying-across-europethrough-the-enable-project ("We are very excited to announce that we are part of a project called ENABLE which is aiming to tackle bullying not just in the UK, but across Europe! Through the Diana Award's Anti-Bullying Ambassador programme we have trained over 15,000 young people to actively take a stand against bullying in their schools and communities.").

${ }^{28}$ See e.g., Jason Hall, Why Men Don't Take Paternity Leave, Forbes (June 14, 2014), http://www.forbes.com/sites/learnvest/2013/06/14/why-men-dont-take-paternity-leave/ (discussing the difficulties around paternity leave, especially the unspoken pressure from employers and coworkers); Jennifer Ludden, More Dads Want Paternity Leave. Getting It Is a Different Matter, NPR (Aug. 13, 2014), http://www.npr.org/2014/08/13/333730249/more-dads-want-paternity-leave-getting-it-is-adifferent-matter ("While an ever-rising share of men say they want to have this kind of time with a new child, Chandran is among a lucky few who actually do. In the U.S., paternity leave is a luxury. It's the only developed nation that doesn't guarantee paid time off, even for new mothers."); Lauren Weber, Why Dads Don't Take Paternity Leave, WALL ST. J. (June 12, 2013), http://www.wsj.com/articles/SB 10001424127887324049504578541633708283670 (discussing further issues around paternity leave, including an expectation of fathers to take work home when taking paternity leave).

${ }^{29}$ See Chris Burke, Report: Richie Incognito Will 'Never Play Another Game' for the Dolphins, SPORTS IllustraTED (Nov. 4, 2013), http://www.si.com/nfl/audibles/2013/11/04/richie-incognitodone-miami-dolphins (reporting on Incognito's indefinite suspension from the Dolphins after the NFL commenced an investigation into alleged bullying of Martin).

${ }^{30}$ See Kelly Wallace, Boomer Esiason Apologizes for C-section Comments, CNN (Apr. 4, 2014), http://www.cnn.com/2014/04/04/living/boomer-esiason-c-sections-paternity-leave-parents/ (discussing Esiason's apology to Murphy and his wife for placing them in the middle of a public discussion and in turn exposing the couple's personal life). 
discourse on these issues continues despite the continued absence of a workplace bullying statute and the inability of many men to vindicate their rights to leave in court.

Another issue that arises is the notion of what is at stake for a worker who asks for or seeks to vindicate rights that are often stigmatized or unpursued. It is not insignificant that the players felt (and were) empowered enough to have parental leave written into the collective bargaining agreements. ${ }^{31}$ It is not insignificant that Murphy felt empowered enough to exercise his option to take it. It should not be lost on us that even the average high-powered white collar working man seems not to feel this way. And there may be repercussions to Murphy having taken his.

\section{As per the Wall Street Journal Blog:}

Murphy's minuscule paternity leave may hurt his fan base a little. His stats might drop down and maybe the Mets will suffer because the season began without a starting player. But in a few years when Murphy isn't playing ball, he and his wife will certainly remember the special moments when they were together as a family for the first time. ${ }^{32}$

Paternity (and maternity) leave have certainly appeared in the news lately. In early August 2015, employer Netflix announced a new, unlimited policy of paid leave for new parents of both sexes in the first year following the birth or adoption of their child. ${ }^{33}$ The announcement garnered lots of attention, mostly because of its generosity in a legal and social climate that does not seem to require such policies on any front. The Chief Talent Officer of Netflix voiced the company's hope to attract, retain, and inspire the most talented and hardworking employees through this generosity. ${ }^{34}$

\footnotetext{
${ }^{31}$ See Jessica Grose, The Lesson From Baseball's Paternity Leave Controversy: Paternity Leave Is Not Controversial, SLATE (Apr. 7, 2014), http://www.slate.com/blogs/xx_factor/2014/04/07/mlb_paternity_leave_controversy_a_happy_ending_ to the_boomer_esiason_flap.html ("Three days of paternity leave has been part of Major League Baseball's collective bargaining agreement since 2011. . . MLB is the only major pro sports league that has parental leave. There's no mention of parental leave in the NBA's collective bargaining agreement - the Miami Heat's Chris Bosh was in a playoff game against the Knicks the same day his son was born in 2012. There's no mention of parental leave in the NFL's collective bargaining agreement, either.").

${ }^{32}$ Catherine Pearlman, Mets Player Daniel Murphy and Why Critics Cry Foul Over Paternity Leave, WALL ST. J. BLOG (Apr. 4, 2014), http://blogs.wsj.com/speakeasy/2014/04/04/mets-sluggerdaniel-murphy-and-why-critics-cry-foul-over-paternity-leave/.

${ }^{33}$ Emily Steel, Netflix Offers Expanded Maternity and Paternity Leave, N.Y. TIMES (Aug. 4, 2015), http://www.nytimes.com/2015/08/05/business/netflix-offers-expanded-maternity-and-paternityleave.html.

${ }^{34}$ See id. ("Netflix's continued success hinges on us competing for and keeping the most talented individuals in their field ....") (quoting Tawni Cranz, Starting Now at Netflix: Unlimited Maternity
} 
Netflix is not alone in affording its employees generous leave benefits above and beyond what the law requires: Twitter offers its employees five months of paid maternity leave and two and a half months of paid paternity leave and Facebook offers four months of paid leave for both new mothers and fathers and a gift of $\$ 4,000$ for each new child born or adopted. ${ }^{35}$ Additionally, in August 2015, Reuters reported that software producer Adobe Systems, Inc. had become "the third company in a week to expand its benefits, doubling maternity leave to twenty-six weeks to increase diversity in its workforce and give parents more time with their newborns." 36 Other companies have followed suit, but the stigma of leave-paternity leave in particular-persists. Reuters recently reported on experts' calls for employers to take the initiative to expand leave policies, noting "[b]etter paid leave for new parents is long overdue in the United States, and executives must lead by example ... ." so as to convince reluctant new parents fearful of being stigmatized to feel comfortable taking advantage of existing laws and policies. ${ }^{37}$

Reporting on a " 2007 study of 173 countries, [in which] researchers at Harvard University and McGill University . . . showed only the United States, Lesotho, Liberia, Papua New Guinea and Swaziland had no paid leave for new mothers," Reuters reasoned that since employers set the amount of time permitted for leave beyond the minimal, unpaid leave required by the law, it is up to America's bosses to improve corporate culture — and the situations of countless employees and their families—by voluntarily setting the bar higher and encouraging employees to take the time off they are entitled to. ${ }^{38}$ Acknowledging that technology and Silicon Valley companies are primarily those taking the lead, this initiative has been connected to job markets in which a so-called sellers' market has transformed into a so-called buyers' market, and top talent is in high demand. But what about markets and industries in which people feel lucky to have jobs, and guard their employment jealously?

The answer may lie in public shaming. The effective public shaming of employers has similarly been in the news lately. However, as in the sports world, people have to care in order for a story to capture the public's interest and outrage and thereby effect change. On August 16, 2015, the New York Times published a piece called "Inside Amazon: Wrestling Big Ideas in a Bruising Workplace," which sought to expose the behemoth

and Paternity Leave, NETFLIX BLOG (Aug. 4, 2015), https://media.netflix.com/en/companyblog/starting-now-at-netflix-unlimited-maternity-and-paternity-leave).

${ }^{35}$ See id. (comparing the leave packages various San Francisco and Silicon Valley companies offer their employees).

${ }^{36}$ Patricia Reaney, Longer Time Off for U.S. Parents Welcome, But Bosses Must Lead the Way, REUTERS (Aug. 10, 2015), http://www.reuters.com/article/work-benefits-idUSL1N10L1AS20150810.

${ }^{37} I d$.

${ }^{38} \mathrm{Id}$. 
employer's acrid, relentless and, arguably, unreasonably demanding corporate culture. ${ }^{39}$ With quotes from employees such as, "[n]early every person I worked with, I saw cry at their desk," were called "utterly devoid of empathy" and "soul-crushing" by media outlets that reported on the response to the controversial, blockbuster New York Times article-which included a backlash against the company. ${ }^{41}$ Among the accusations made in the New York Times article were the following: that employees stricken with cancer were told that they had low productivity, that those experiencing personal and family tragedies were discouraged or penalized for taking time to deal with their situations, and that all employees were being encouraged to criticize and report upon fellow employees via clandestine mechanisms. ${ }^{42}$

The public's fascination with the internal goings-on of such a widely patronized and heard-of company propelled what are likely common employment practices into the spotlight and sparked a swift and severe backlash against Amazon. Within days of the New York Times article's publication, Amazon CEO Jeff Bezos, clearly on the defensive, responded to it in a letter to his employees, asserting that the article portrayed a workplace that was virtually unrecognizable to him. ${ }^{43}$ Denying many of the allegations made, he also stated that Amazon would not put up with "the shockingly callous management practices" described and told employees that "tolerance for any such lack of empathy needs to be zero," imploring those who had experienced any aspect of the culture described in the article to get in touch with him so that things could be rectified. ${ }^{44}$

Within a few days, an Amazon executive had appeared on a major television network's morning show to mount a similar defense. ${ }^{45}$ Similar

\footnotetext{
39 See Jodi Kantor \& David Streitfeld, Inside Amazon, Wrestling Big Ideas in a Bruising Workplace, N.Y. TIMES (Aug. 15, 2015), http://www.nytimes.com/2015/08/16/technology/insideamazon-wrestling-big-ideas-in-a-bruising-workplace.html (reporting on Amazon's "way of working").

${ }^{42}$ See Kantor \& Streitfeld, supra note 37 ("A woman who had thyroid cancer was given a low performance rating after she returned from treatment. ... A woman who had breast cancer was told that she was put on a 'performance improvement plan'-Amazon code for 'you're in danger of being fired'because 'difficulties' in her 'personal life' had interfered with fulfilling her work goals.").

${ }^{43}$ Jodi Kantor \& David Streitfeld, Jeff Bezos and Amazon Employees Join Debate Over its Culture, N.Y. TIMES (Aug. 17, 2015), http://www.nytimes.com/2015/08/18/technology/amazon-bezosworkplace-management-practices.html.

${ }^{44} I d$.

${ }^{45}$ David Streitfeld \& Jodi Kantor, Jeff Bezos \& Amazon Employees Join Debate Over its Culture, N.Y. TIMES (Aug. 17, 2015), http://www.nytimes.com/2015/08/18/technology/amazon-bezosworkplace-management-practices.html ("Jay Carney, Amazon's chief spokesman, appeared on 'CBS This Morning' to defend the company ....").
} 
defenses were mounted on online media and social networking sites. ${ }^{46}$ The defense of the company and its proactive stance were as swift as the attacks had been, but one has to wonder what the plight of those pushed to and beyond their limits might have been if the news about what was going on had never seen the light of day — or if no one had cared much once they had.

The Mets, paternity leave, and another public spectacle were in the news again in July 2015, when - on one summer Friday night at Citi Field-as the New York Post reported:

The Dodgers were without star right-hander Zack Greinke, who was on paternity-list leave and back in Los Angeles with his wife... after she gave birth to the couple's first child... on Thursday. Mets left-hander Jon Niese, meanwhile, was written in all along as the scheduled starter. But just a few hours before game time against the Dodgers... "Jon's wife...is due any minute," with the couple's second child, manager Terry Collins said before the Mets' 7-2 loss. "Could we have anything else happen?" Niese was on-call for his wife as the couple expected their second child. Niese...made his start - while his wife gave birth to a baby boy... [and] flew out to join his family while the game was still in progress. ${ }^{47}$

The article reported that one of Niese's teammates expressed his "surprise" that Niese chose to show up for the game, but added that "it shows the type of guy he is," further reinforcing the image of an employee that foregoes being present for the birth of his child as a superior employee. ${ }^{48}$ So cycles around the seemingly never-ending debate over the stigmatization and discouragement of male employees from taking leave.

Baseball and the sports world at large may be seen as a hotbed of bullying, discrimination, and exclusion. But may it not also be seen as a very public stage upon which issues have a chance to become embedded in the public's consciousness and capture its attention in ways that similar situations which occur in more traditional workplaces do not? Should we not be mindful of, and perhaps look for ways to, harness and capitalize upon the power of this public stage and the players upon it to accomplish, through the media, what legislatures and litigants cannot? This awareness, and the answers to these questions, may help to bridge the somewhat

${ }^{46}$ Michal Addady, Amazon Staffer Defends His Company Against New York Times, FoRTUNE (Aug. 16, 2015), http://fortune.com/2015/08/16/amazon-new-york-times-response/ (Amazon's head of infrastructure development responded on LinkedIn to defend Amazon).

${ }^{47}$ Fred Kerber, Jon Niese Makes Start, Watches Son's Birth on FaceTime, N.Y. PosT (July 24, 2015), http://nypost.com/2015/07/24/baby-havoc-for-mets-dodgers-as-2-pitchers-wives-go-into-labor/.

${ }^{48}$ Id. 
widening gap between sports organizations and many of their fans. More importantly, they may also help reconcile the issues that people seem to truly care about when they are given proper exposure to both the underlying problems and the failure to reach a solution through traditional legislative and judicial outlets such as proposed bills and filed lawsuits. 